\title{
Labour Dynamics in Climate and Techno Reliant Small Scale Maize Production
}

\author{
Ardinesh Kambanje, Saul Ngarava*, Abyssinia Mushunje, Amon Taruvinga \\ Department of Agricultural Economics and Extension, University of Fort Hare, South Africa \\ 201103933@ufh.ac.za,201501225@ufh.ac.za,AMushunje@ufh.ac.za,ATaruvinga@ufh.ac.za
}

\begin{abstract}
Adoption of improved technology tends to recalibrate labour use in agricultural production. The study examined how the adoption of various maize varieties impacted labour use in smallholder production. The study utilised a structured pre-coded questionnaire-based survey of 487 smallholder maize farmers in South Africa. The purposive sample was obtained from Ingquza Hill and Port St John's Local Municipalities in the Eastern Cape Province. A multinomial regression model and Monte Carlo Simulation were utilised to analyse the data. Statistical Package for Social Scientist (SPSS) version 23 as well as Excel were the statistical tools utilised. Through multinomial regression analysis, the study found that weeding labour was the most significantly affected by a change in maize variety. It was observed that as maize variety transcends in use from Landrace to GMO, improved OPV and conventional hybrid, ploughing and weeding hours tend to decrease. The harvesting, storage and shelling hours tend to increase. Utilising the Monte Carlo Simulation, the study also found an increased impact of maize variety utilisation on harvesting as well as on shelling and storage labour hours. The study recommends that varieties be promoted taking cognizance of the labour dynamics to tier maximize suitability and labour-based productivity, reducing tedious labour use in ploughing and weeding, whilst promoting employment in harvesting, shelling and storage.
\end{abstract}

Keywords: Improved Maize Varieties, Labour, Monte Carlo Simulation, South Africa

\section{Introduction}

Low input subsistence agriculture has been a major contributing factor to food security and improved rural livelihoods in developing countries. The World Bank (2008) indicates that it is significant in sustainable development, poverty reduction and enhanced food security. However, despite this significant recognition, agricultural productivity has continued to decline, with poverty levels increasing (Ouma and De Groote, 2011). Various factors have been attributed to this decline; chief amongst them being climate change and variability. In that scenario, various technologies have been developed to boost agricultural production, taking aim at the two-tier impacts of increased productivity in a dynamic climatic environment. More so, this technological advancement has been more evident in the production of maize, a staple crop in most third world countries (Regier and Dalton, 2013). South Africa has been one of the leading countries in the aspect of maize technology advancement and utilization, realizing an increase in maize output in tonnage from 6.9 million in 2006 to 14.9 million in 2014. However, production has gradually been decreasing from thereon to 7.7 million in 2016 (Quantec easy data, 2017a). This is despite the year on year area planted change decreasing by 36.5\%, $4.39 \%$ and 25.85\% in 2006, 2014 and 2016 respectively (Quantec easy data, 2017b). The country has been at the forefront in innovating Genetically Modified (GM) maize, as well as increasing use of hybrid maize in Sub-Saharan Africa.

James, (2014) identifies South Africa occupying $9^{\text {th }}$ position in the world in terms of biotech crop production, with 2.7 million hectares under enhanced crop production. According to the Global Harvest Initiative, (2017) South Africa is the only country where small-scale farmers have been growing GMOs in the past 10 years. Among the various maize varieties grown in the country include $B_{t}$ maize, which was introduced in 1988 , and $\mathrm{H}_{\mathrm{t}}$ maize, introduced in 2003, with "stacked" maize combining both traits introduced in 2009. Out of the total maize producing areas in South Africa in 2012, 43\% was stacked, 29\% Bt and 13\% $\mathrm{H}_{\mathrm{t}}$ (Global Harvest Initiative, 2017). Mbofung (2010) highlights that the use of this improved maize varieties and technologies has enabled an increase in crop yields, improved storage potential, protein content, bio-fortification and improved food functionality. This has made South Africa the $10^{\text {th }}$ largest producer of maize in the world, and since 1971 the country has topped 14.9 million tonnes in 2014 and bottoming 3.3 million tonnes in 1992 due to the climate change-induced drought (Quantec easy data, 2017a). However, with technological advancement comes the downside. Besides the most documented concerns relative to food safety, enhanced 
advancement in technology has recalibrated labour use in agricultural production, rendering it redundant in some instances. Being one of the most significant and abundant factors of production in developing countries, underutilisation and/or contraction of the labour based opportunities has also been a contributing factor to depleted poverty reduction.

Gouse, Piesse, Thirtle and Poulton (2009) indicated that introducing a labour saving technology in a labour abundant economy, labour incomes fall and poverty increases. This presents a quagmire to planners and policymakers. The major question rose to be the trade-off between poverty-reduction-based technology advancement or labour enhancement (Gouse et al., 2009). In addition, previous studies have blanketed findings, disregarding area specific dynamics in terms of climatic variability. Be it as it may, such fundamental decisions cannot be made in a vacuum, there requires in-depth valuations. This necessitates the current study, which identifies how the adoption of various crop technologies has influenced labour dynamics. Specifically, the paper examines how the adoption of various crop varieties in differing climatic regions will likely impact labour use in small-scale maize production.

\section{Labour Use in Maize Production}

Labour is a significant factor of production in maize husbandry, which has attracted a share amount of academic attention (Regier and Dalton, 2013; Gouse, Sengupta, Zambrano and Zepeda, 2016; Gouse, 2014). This was corroborated by Leonardo et al. (2015) who found labour having more significance in addressing maize productivity in Mozambique relative to land. Smallholder farmers are efficient users of their production resources, especially labour. Family labour use for example, has been found to enhance smallholder production activities (Gouse et al., 2016), a phenomenon now regarded as the inverse farm size relationship. Furthermore, subdividing this labour, weeding was the main category determining maize yields (Leonardo et al., 2015). This was supported by Gouse et al. (2016) and Global Harvest Initiative, (2017) identifying a 10 to 12-day reduced weeding time in utilising improved maize varieties in South Africa. In addition, this played to the household dynamics, where females were more involved in agricultural production, freeing them to pursue other household chores. Alhassan, Salifu and Adebanji, (2016) corroborated labour being a significant determinant of improved maize variety adoption in Ghana. In Bangladesh, Karim, Moniruzzman and Alam (2010) discovered labour cost accounting for 33\% of variable costs in the use of maize varieties, with much of this labour being hired. Human labour coefficient was identified having a significant impact on gross return in maize enterprises (Karim et al., 2010).

In terms of scale, larger scale farmers tend to achieve better yield because of their ability to hire labour, especially during weeding, relative to the small-scale maize farmers, who actually hired out their labour. Leonardo et al. (2015) highlighted intensive maize production being labour saving relative to extensive. In South Africa, Gouse, Piesse and Thirtle (2006) found the use of GM maize displacing labour, negatively affecting the poverty status of the households. For instance, they found the use of non-tillage maize varieties reducing labour input by 63\%, especially in weeding and land preparation. However, Regier and Dalton, (2013) found total labour cost increases for GM maize, suggesting a recalibration of labour from other aspects of husbandry, but ultimately increasing the cost of labour. They highlighted that non-tillage maize varieties tend to reduce weeding labour as it is replaced through herbicide use. Bamire et al. (2010) corroborate, indicating that adoption of new technologies implies need in additional labour, making adoption less attractive to farmers with limited labour. Subdividing labour use between children, gender and hired labour amongst various maize varieties, Regier and Dalton, (2013) found higher labour use in non-GMO maize varieties with females providing a greater share of this labour. The labour used reduced slightly as maize variety changed from Bt, Round Ready and a combination of both. Interestingly, hired labour was lower for Bt and Round Ready maize varieties, but however higher for the combinational variety (Regier and Dalton, 2013).

Gouse (2014) corroborates with findings of small-scale farmer search of best land preparation and planting method. Furthermore, improved maize varieties increased the cost of production with cost savings in land preparation, planting and weeding. There was lower labour demand in land preparation and weeding in notillage varieties which were however not modified or hybrid. In addition, as the maize variety usage 
transcended from saved seed with manual weeding through old hybrid, also with manual weeding, up to $B_{t}$ and $\mathrm{H}_{\mathrm{t}}$ maize utilisation, the yield per labour day also tends to increase. This was through the tier effect of an increase in maize output and reduction in labour days (Gouse, 2014). Literature related to labour used in maize enterprises has had mishaps especially relating to disaggregating in on how it is utilised (Karim et al, 2010; Regier and Dalton, 2013). Factoring in the maize variety use (Sibiya, Tongoona, Derera and Makanda, 2013; Grouse, 2014) as well as furthering with climatic variability (Alhassan et al., 2016), studies relating to such have been few and far in between. This is particularly significant in the instance where labour has been identified as significant in improving maize enterprise returns.

Karim et al. (2010) proved this by identifying a 1\% increase in labour leading to a $43.1 \%$ increase in gross returns in Bangladesh. Alhassan et al. (2016) identified that socio-economic circumstances tend to shape maize technology adoption, "cautiously" determined by the climatic variability. In Ghana, contrary to literature, they discovered labour use in farmers that adopt improved maize varieties being higher. The labour dynamics were a significant factor in adoption decision, but the study also fell short in disaggregating this labour use (Alhassan et al., 2016). Gouse (2014) highlighted labour demand bottleneck in land preparation, planting and weeding negatively and significantly impacting maize yield and expansion. Putting the rural to urban migration in rural South Africa into perspective, this has made agricultural land productively inert. According to Regier and Dalton (2013), the impact of improved maize varieties depends on input availability. For instance, if labour is abundant, labour incomes fall and poverty increases. Conversely, if there is plentiful land planting area and output increase and thus higher labour use and higher wages. South Africa is endowed with abundant marginal land (Regier and Dalton, 2013), with a constrained farm labour supply. Furthermore, a rise in labour has a differing effect on input demand for improved maize variety use. Improved maize variety users are more likely to substitute this labour with fertilisers, less seed and herbicide (Regier and Dalton, 2013). However, such assertions are put into question when the labour use has been aggregated in these studies. Furthermore, the climate variability will also likely recalibrate labour use in the various arrays of maize husbandry. This forms the core objective of the current study, to add knowledge on how labour use is recalibrated in the two-tier wake of maize variety and climate variability.

\section{Methods and Material}

The study covered two local municipalities in the O. R Tambo district municipality (ORTDM) namely Port St John's and Ingquza Hill as shown in Figure 1 below. In each local municipality one area was selected based on the prevalence of potential maize production and these are Port St John's-rural and Flagstaff respectively. The district has a land area of 12096 square kilometres, with 92 percent constituting of rural $(90.22 \%$ on tribal land) and 8 percent urban (Department of Local Government, 2012; McCann, n. d.). The population in the ORTDM increased from an estimated 1771176 people in 2003 to 1961815 in 2013 (ECSECC, 2014). With six of its seven local municipalities classified as category B4-Municipalities (except for King Sabata Dalindyebo Local Municipality), this signifies that they are rural or mainly a subsistence economy where settlements are small and the incomes of their inhabitants low. In the district, agriculture is the major private sector activity though its potential remains largely untapped, contributing about $8 \%$ to the formal employment, and a mere 1.8\% to the districts GDP (IDP, 2016; Department of Local Government, 2012) on an unemployment base and dependency ratio of $70.76 \%$ and 4.06 , respectively (McCann, n.d.). The ORTDM has good fertile soils, with favourable climatic conditions, abundant land with suitable terrain on river valleys providing irrigations from abundant water sources and huge market (ORTDM, 2007). Furthermore, maize is the dominant crop being cultivated in the district. 


\section{Figure 1: Map Showing the Location of the Two Study Sites in the Eastern Cape Province}

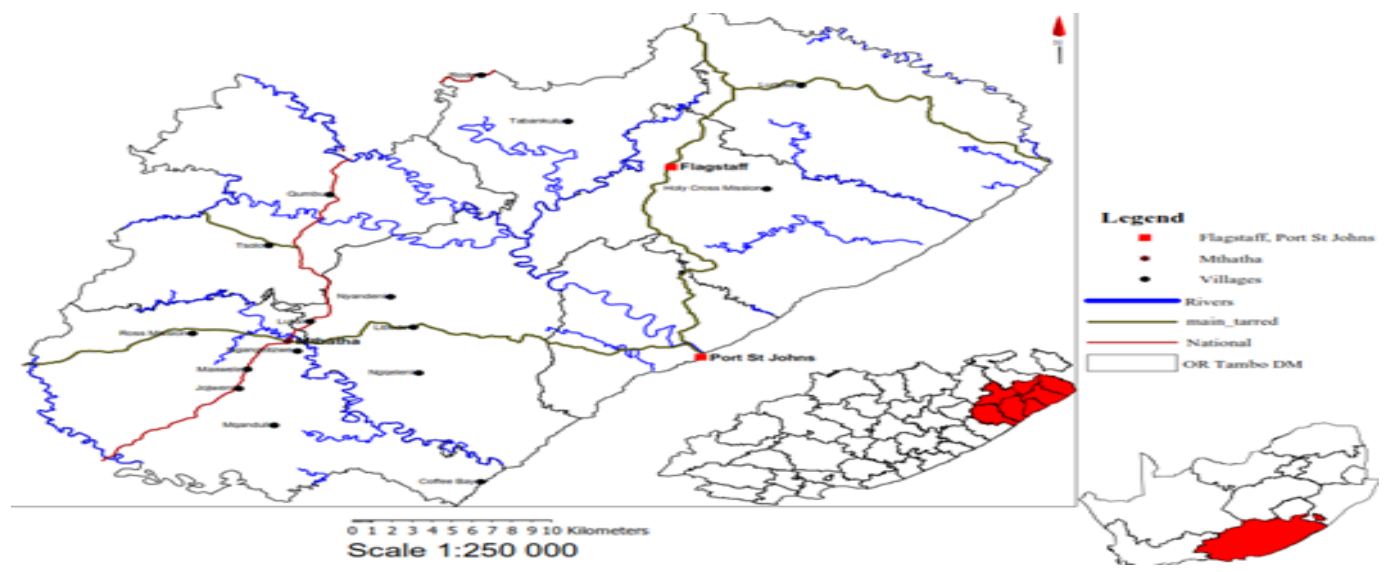

Source: Constructed from www.geoinfo.statssa/gov.za/censusdigitalatlas/ by GIS Department, University of Fort Hare. Ingquza Hill Local Municipality (IHLM) was selected because of its great agricultural potential availed by large tracts of fertile rural land (IDP, 2009) and subtropical climate with relatively high rainfall. Flagg staff in Ingquza Hill receives $749 \mathrm{~mm}$ rainfall annually, with a temperature range of $19.3-25.2^{\circ} \mathrm{C}$ (Figure 2).

\section{Figure 2: Average Rainfall and Temperature in Flagstaff, Ingquza Hill Local Municipality}

(a) Average rainfall

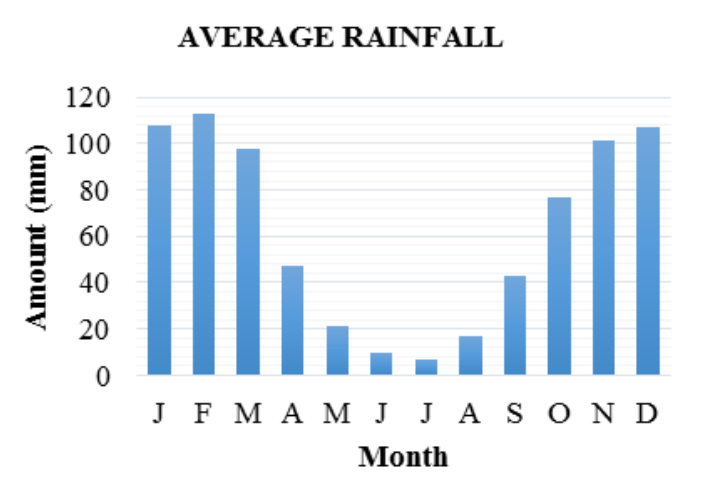

(b) Average temperature

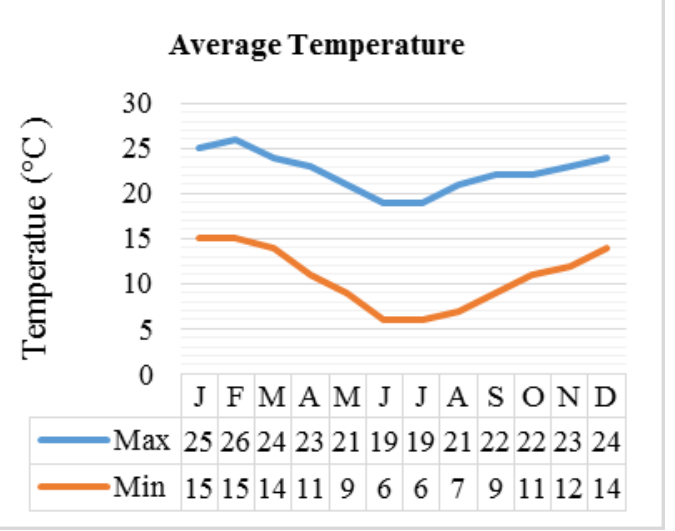

Source: SA Explorer (2014)

Agriculture is the predominant form of land use in IHLM, growing mainly maize, with small-scale farming supplementing nutritional needs and generating income for the highly unemployed (KPA3, n. d.). The area is mostly hilly, with alluvial soils lacking in phosphorous and potassium (Mandikiana, 2011), with most farms between one and two hectares close to homesteads. Family labour as well as seasonal workers (paid in kind) are the forms of labour, with people working the land by hand and small-scale mechanization. Port St John was selected because of its high maize production by smallholder farmers with some in irrigation. The area receives $990 \mathrm{~mm}$ annually, with however a more even distribution as compared to Flagg staff, with a temperature range of $21-25.8^{\circ} \mathrm{C}$ (Figure 3). 
Figure 3: Average Rainfall and Temperature in Port St John, Port St Local Municipality

(a) Average rainfall

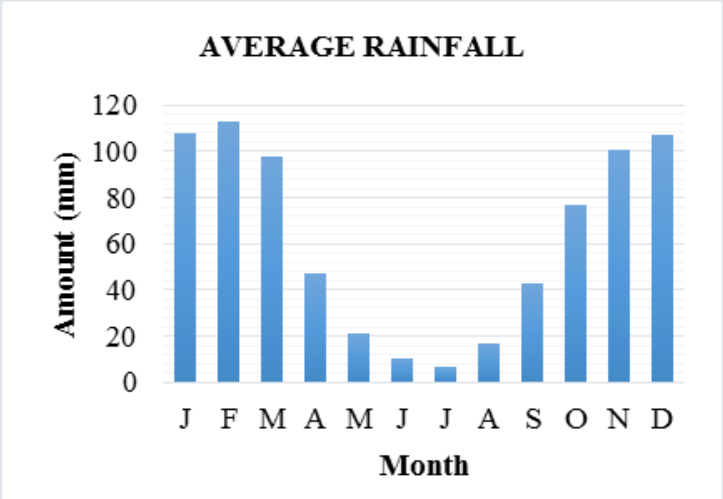

(b) Average temperature

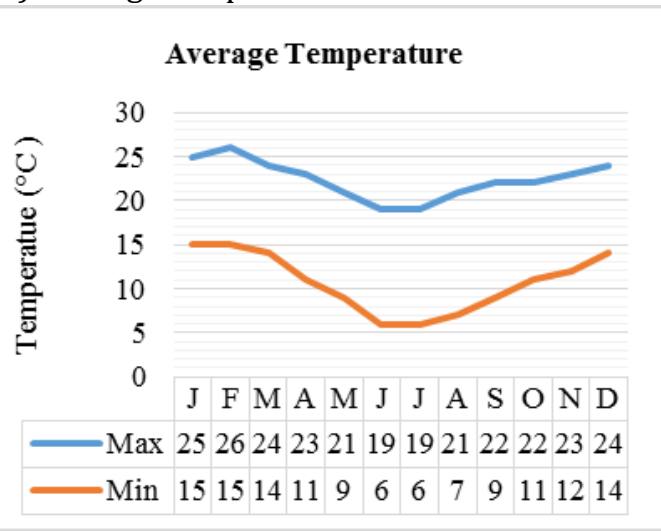

Source: SA Explorer (2014)

Agriculture is also a predominant land use in Port St John, with however a mere 5.6\% contribution to the Local Municipality's Gross Geographical Product (GGP) (PSJM, n. d.), where over 80\% of the local people are unemployed, with $40 \%$ people in the rural areas neither able to read nor write (SALN, n. d.). Agriculture is mainly subsistence, with the production of poultry, vegetables and maize predominating. Informal trading and social grants largely drive Port St John economy, with a largely illiterate and limited skilled labour force (PSJM, n. d.). The study used a cross-sectional, descriptive and quantitative survey of smallholder dry and irrigated maize producers. A structured pre-coded questionnaire was used as the research instrument for data collection to interview smallholder farmers in the study area. The data collected included socioeconomic, demographics, labour use in various stages of maize production and the maize variety is grown. For the purpose of capturing a well-represented sample of the smallholder farmers in the study area, multiple sampling was used as the sampling technique. Amongst the district municipalities in Eastern Cape Province, O. R Tambo District Municipality was purposively selected because of the prevalence of the crop. With five local municipalities in 0. R Tambo District Municipality, two were also purposively selected, Ingquza Hill (Moderate rainfall) and Port St John's (High rainfall), due to differences in agro-ecological zones and climatic conditions.

Based on information from extension officers working in the study sites, Flag staff has 10 wards that are into maize production whilst Port St John's has 13 wards. Therefore, random sampling of the required number of wards was done from the above-mentioned wards. From the given number of wards, villages to interview were purposively selected. Convenience sampling was used in these villages to select households to interview. A sample size of 487 smallholder farmers was randomly drawn with sample sizes varying from one ward to the other and from local district municipality to the other. Descriptive statistics, multinomial regression and Monte Carlo Simulation (MCS) were used to analyze the results. Multinomial regression is utilised in predicting the probability of category membership of a dependent variable based on independent variables (Schwab, 2002). It is a reliable model because of the reduced assumptions concerning normality, linearity or homoscedasticity. In the multinomial regression model, considering individual choosing maize variety amongst $n$ alternatives in a choice set, with $X_{1_{\mathrm{m}} n}$ independent variables (labour use), the $\log$ it for each non-reference category $j=1, \ldots, C-1$ against the landrace maize variety category $(0)$ depends on the values of the independent variables (labour use), with probability parameters $\pi_{i}^{(0)}, \pi_{i}^{(1)}, \ldots, \pi_{i}^{(C-1)}$ through:

$\log \left(\frac{\pi_{i}^{(j)}}{\pi_{i}^{(0)}}\right)=\beta_{0}^{(j)}+\beta_{1}^{(j)} X_{1 i}+\cdots+\beta_{k}^{(j)} X_{k i}$

for each $j=1, \ldots, C-1$ where $\beta_{0}^{(j)}, \ldots, \beta_{k}^{(j)}$ are unknown population parameters. This expands to: 


$$
\begin{gathered}
\log \left(\frac{\pi_{i}^{(j)}}{\pi_{i}^{(0)}}\right)=\beta_{0}^{(j)}+\beta_{1}^{(j)} P L O_{\text {hrs } / h a}+\beta_{2}^{(j)} P L A_{\text {hrs } / h a}+\beta_{3}^{(j)} W E E_{\text {hrs } / \text { ha }}+\beta_{4}^{(j)} H A R_{\text {hrs } / h a} \\
+\beta_{5}^{(j)} S H E \& S T O_{\text {hrs } / \text { ha }} \cdots+\mu
\end{gathered}
$$

Where the independent variables include the hours per hectare of: $P L O U$-the ploughing, $P L A$-planting, $W E E$-weeding, $H A R$-harvesting and $S H E$ \& $S T O$-shelling and storage as well as $\mu$-error term.

Monte Carlo Simulation (MSC) is a probability simulation utilised to measure variability, through estimating a range of values rather than relying on single discrete values (Mary, Phi mister and Roberts, 2013). This creates a more realistic picture of what occurs in reality. It generates random variables for modelling uncertainty (The Economic Times, 2018). A simulation model was determined to include uncertainty in the deterministic labour use identified for the most significant maize variety in transiting from the landrace maize base category. Consider

$\varphi=E_{\pi}\{U(X)\}=\int U(x) \pi(x) d x$

Where $E_{\pi}\{\}$ is the expectation with respect to the probability density $\pi$ and $X=\{\tau, \omega\}$ is a vector of decision parameters i.e. total labour, $\tau$, and a combination, $\omega$, of system parameters i.e. labour (ploughing, planting, weeding, harvesting and shelling and storage) and state variables calculated by the models. The symbol $U()$ denotes a response function in this case the total labour. The MCS evaluates the integral by generating random draws $X=x^{m}$ from the target distribution $\pi$ and then estimating $\varphi$ as the average of $U\left(x^{1}\right), \ldots, U\left(x^{k}\right)$ where $k$ is the number of replications.

As alluded to earlier, $\omega$ is a combination of system parameters (i.e. the state of nature), $\omega_{0}$, and state variables $\omega_{s}=\left\{\omega_{1 s}, \ldots, \omega_{T s}\right\}$ calculated by the model. This splitting produces the following reformulation: $\varphi=E_{\pi_{0}}\left\{E_{\pi_{s]_{0}}}\{U(X)\}\right\}=\int\left\{\int U(x) \frac{\pi(x)}{\pi_{0}\left(\omega_{0}\right)} d\left\{\tau_{,} \omega_{s}\right\}\right\} \pi_{0}\left(\omega_{0}\right) d \omega_{0}$

Where $E_{\pi_{0}}\{\}$ is the expectation with respect to the probability density $\pi_{0}$ of the state of nature and $E_{\pi_{s ! 0}}\{\}$ is the expectation with respect to the conditional probability density given a state of nature. The double integral may be numerically evaluated through drawing $n$ states of nature, $\omega_{0}^{1}, \ldots, \omega_{n}^{n}$, at random from the distribution $\pi_{0}$. Random sampling for each $q$ observation from the distribution $\pi_{s l_{0}}$ is created by the simulations $q$ times. Thus the total number of simulations run equals $p=n \times q$ (Kristensen and Pedersen, 2003).

\section{Results and Discussion}

Descriptive Results: Table 1 shows that the average age of the total respondents was 58 years, lower in Ingquza Hill (56) and higher in Port St John's (59). There was a lower age range for the respondents in Port St John's (62 years) relative to Ingquza Hill (72 years). In both areas, most of the maize producers were predominantly female, with primary education, with those in Ingquza Hill being single relative to married in Port St John's. On average, collectively, the dependency ratio of the respondents was 1.9, with Ingquza Hill and Port St John's individually having dependency ratios of 1.57 and 2.44. Most of the respondents were formally employed, who were also however dependent on social grants. In terms of labour use, respondents in Port St John's on average utilise $46.5 \mathrm{hrs}$ /ha relative to $79.9 \mathrm{hrs} / \mathrm{ha}$ in Ingquza Hill in terms of ploughing. Planting labour hours for maize producers in Port St John's average $39.5 \mathrm{hrs} / \mathrm{ha}$ relative $54.7 \mathrm{hrs} / \mathrm{ha}$ in Ingquza Hill. Port St John's maize producers tend to utilise $173.1 \mathrm{hrs} / \mathrm{ha}$ for weeding relative to $202.0 \mathrm{hrs} / \mathrm{ha}$ in Ingquza Hill. In terms of harvesting and shelling and storage, Port St John's maize producers utilise 100.1 $\mathrm{hrs} / \mathrm{ha}$ and $204.2 \mathrm{hrs} / \mathrm{ha}$ respectively, relative to $121.8 \mathrm{hrs} / \mathrm{ha}$ and $222.5 \mathrm{hrs} / \mathrm{ha}$ respectively for Ingquza Hill. 
Empirical Results: For referral purposes, the landrace variety was chosen as the reference category because it is the most common and environmentally adapted amongst the maize varieties used in the study area. Table 2 shows that the ploughing labour hours of a maize producer transiting from producing landrace to producing GMO is significant $\left(P_{\text {value }}<0.01\right)$. This is observed for maize producers in Port St John's where the negative coefficient indicates that as the maize variety is changed from landrace to GMO, the labour hours devoted to ploughing tend to decrease. There are two prong explanations to this finding: either (1) because of improved mechanization by farmers in the study area, labour hours devoted to ploughing has substantially reduced or (2) because of extension advice concerning GMO utilization being weed or pest resistant, the ploughing labour hours to reduce weeds and pests therefore become redundant. These findings are supported by Gouse et al. (2006) and Gouse, (2014) identifying cost savings in land preparation. The log odds ratio indicates a $0.9 \%$ likely chance of the labour hours decreasing. This is however not the case in Ingquza Hill, where the labour hour differences are not significant, mostly because the farmers utilise less mechanisation. From observation in the field, Ingquza Hill farmers exhibited free rider tendencies, lacking motivation in producing maize and thus inert to ploughing recommendations, especially when utilizing improved maize varieties.

In terms of planting labour hours, there exist no significant differences whether a maize farmer transits from using landrace to utilising GMO, Sahara, Hybrid or all inclusive. This is because planting labour required to plant equal hectarage of any maize variety is unlikely to change dependent upon the maize variety used. This is in stark contrast to Gouse, (2014) who identified a cost saving in planting labour induced by improved maize varieties. Weeding labour hours tend to be significantly different for Ingquza Hill maize farmers when they change from landrace variety to GMO $\left(P_{\text {value }}<0.01\right)$, Sahara $\left(P_{\text {value }}<0.1\right)$ as well as combining landrace with GMO $\left(P_{\text {value }}<0.05\right)$ respectively. The negative coefficients suggest that as this transition takes effect, the amount of weeding labour tends to decrease. The log odd ratios indicate a $0.5 \%, 0.2 \%$ and $0.3 \%$ likely chance of weeding labour hours decreasing when transiting from landrace to GMO, Sahara and combination of landrace with GMO respectively. This is also true for maize farmers in Port St John's transiting from landrace to GMO, combining landrace and GMO $\left(P_{\text {value }}<0.01\right)$ as well as combining GMO and Sahara $\left(P_{\text {value }}<0.1\right)$ respectively. The log odd ratios in this instance indicate a $0.7 \%, 1.2 \%$ and $1.5 \%$ likely chance of weeding labour reduction respectively. This is because utilisation of improved maize varieties which are weed and pest tolerant tend to decrease labour devoted to weeding. This speaks directly to Leornardo et al. (2015).

Table 1: Descriptive Results

\begin{tabular}{|c|c|c|c|c|c|c|c|c|c|c|c|c|c|}
\hline \multirow{2}{*}{\multicolumn{2}{|c|}{ Variable }} & \multicolumn{4}{|c|}{ Overall (n=487) } & \multicolumn{4}{|c|}{ Ingquza Hill $(n=247)$} & \multicolumn{4}{|c|}{ Port St. John's (n=240) } \\
\hline & & Min & Max & Mean & $\begin{array}{l}\text { Std. } \\
\text { Dev. }\end{array}$ & Min & Max & Mean & $\begin{array}{l}\text { Std. } \\
\text { Dev. }\end{array}$ & Min & Max & Mean & $\begin{array}{l}\text { Std. } \\
\text { Dev. }\end{array}$ \\
\hline \multicolumn{2}{|l|}{ Age } & 19 & 91 & 57.78 & 13.635 & 19 & 91 & 56.47 & $\begin{array}{l}14.46 \\
0\end{array}$ & 25 & 87 & 59.13 & 12.618 \\
\hline \multirow{2}{*}{\multicolumn{2}{|c|}{$\begin{array}{l}\text { Gender } \\
\text { Educational level }\end{array}$}} & & & Female & & & & Female & & & & Female & \\
\hline & & Non & Tertiary & Primary & & Non & Tertiary & Primary & & Non & $\begin{array}{l}\text { Terti } \\
\text { ary }\end{array}$ & Primary & \\
\hline \multicolumn{2}{|c|}{ Marital status } & & & Married & & & & Single & & & & Married & \\
\hline $\begin{array}{l}\text { househol } \\
\text { d }\end{array}$ & $\begin{array}{l}16-40 \\
\text { years }\end{array}$ & 0 & 14 & 2.50 & 2.034 & 0 & 10 & 2.85 & 2.007 & 0 & 14 & 2.13 & 2.001 \\
\hline \multirow[t]{2}{*}{$\begin{array}{l}\text { composit } \\
\text { ion }\end{array}$} & $\begin{array}{l}\text { 41-65 } \\
\text { years }\end{array}$ & 0 & 8 & 1.28 & 1.086 & 0 & 8 & 1.11 & 0.961 & 0 & 6 & 1.47 & 1.175 \\
\hline & $\begin{array}{l}\text { Above } \\
65 \\
\text { years }\end{array}$ & 0 & 4 & 0.49 & 0.788 & 0 & 3 & 0.30 & 0.648 & 0 & 4 & 0.70 & 0.864 \\
\hline \multicolumn{2}{|c|}{ Employment status } & $\begin{array}{l}\text { Une } \\
\text { mplo } \\
\text { yed }\end{array}$ & $\begin{array}{l}\text { Full } \\
\text { time } \\
\text { farmer }\end{array}$ & $\begin{array}{l}\text { Formally } \\
\text { employe } \\
\text { d }\end{array}$ & & $\begin{array}{l}\text { Unem } \\
\text { ployed }\end{array}$ & $\begin{array}{l}\text { Full } \\
\text { time } \\
\text { farmer }\end{array}$ & $\begin{array}{l}\text { Formall } \\
\text { y } \\
\text { employ } \\
\text { ed }\end{array}$ & & $\begin{array}{l}\text { Une } \\
\text { mplo } \\
\text { yed }\end{array}$ & $\begin{array}{l}\text { Full } \\
\text { time } \\
\text { farm } \\
\text { er }\end{array}$ & $\begin{array}{l}\text { Formally } \\
\text { employe } \\
\text { d }\end{array}$ & \\
\hline \multicolumn{2}{|c|}{ Source of income } & & & $\begin{array}{l}\text { Social } \\
\text { grants }\end{array}$ & & & & $\begin{array}{l}\text { Social } \\
\text { grants }\end{array}$ & & & & $\begin{array}{l}\text { Trading/ } \\
\text { business }\end{array}$ & \\
\hline \multicolumn{2}{|c|}{ Ploughing hrs/ha } & 0.20 & 1800.00 & 63.4215 & 158.948 & 0.34 & 1800.00 & 79.8636 & 180.4 & 0.20 & 1306. & 46.5000 & 131.47 \\
\hline
\end{tabular}


Journal of Economics and Behavioral Studies (ISSN: 2220-6140)

Vol. 10, No. 4, pp. 262-276, August 2018

\begin{tabular}{|c|c|c|c|c|c|c|c|c|c|c|c|c|}
\hline Planting hrs/ha & 0.20 & 1250.00 & 47.1790 & $\begin{array}{l}64 \\
106.177 \\
10\end{array}$ & 0.34 & 1250.00 & 54.6721 & $\begin{array}{l}6767 \\
121.8 \\
3473\end{array}$ & 0.20 & $\begin{array}{l}67 \\
653.3 \\
3\end{array}$ & 39.4675 & $\begin{array}{l}479 \\
86.765 \\
86\end{array}$ \\
\hline Weeding hrs/ha & 0.00 & 2800.00 & 187.7364 & $\begin{array}{l}307.986 \\
38\end{array}$ & 0.00 & 2800.00 & $\begin{array}{l}201.954 \\
0\end{array}$ & $\begin{array}{l}319.7 \\
1399\end{array}$ & 0.00 & $\begin{array}{l}1960 . \\
00\end{array}$ & $\begin{array}{l}173.104 \\
0\end{array}$ & $\begin{array}{l}295.38 \\
375\end{array}$ \\
\hline Harvesting hrs/ha & 0.00 & 960.00 & 111.0897 & $\begin{array}{l}118.556 \\
97\end{array}$ & 0.00 & 960.00 & $\begin{array}{l}121.773 \\
6\end{array}$ & $\begin{array}{l}127.4 \\
7780\end{array}$ & 0.00 & $\begin{array}{l}672.0 \\
0\end{array}$ & $\begin{array}{l}100.094 \\
1\end{array}$ & $\begin{array}{l}107.77 \\
787\end{array}$ \\
\hline $\begin{array}{l}\text { Shelling and storage } \\
\text { hrs/ha }\end{array}$ & 0.00 & 2415.00 & 213.5014 & $\begin{array}{l}288.430 \\
77\end{array}$ & 0.00 & 2415.00 & $\begin{array}{l}222.545 \\
6 \\
\end{array}$ & $\begin{array}{l}314.7 \\
9018 \\
\end{array}$ & 0.00 & $\begin{array}{l}1960 . \\
00\end{array}$ & $\begin{array}{l}204.193 \\
4\end{array}$ & $\begin{array}{l}258.84 \\
862 \\
\end{array}$ \\
\hline
\end{tabular}

Table 2: Multinomial Regression Results

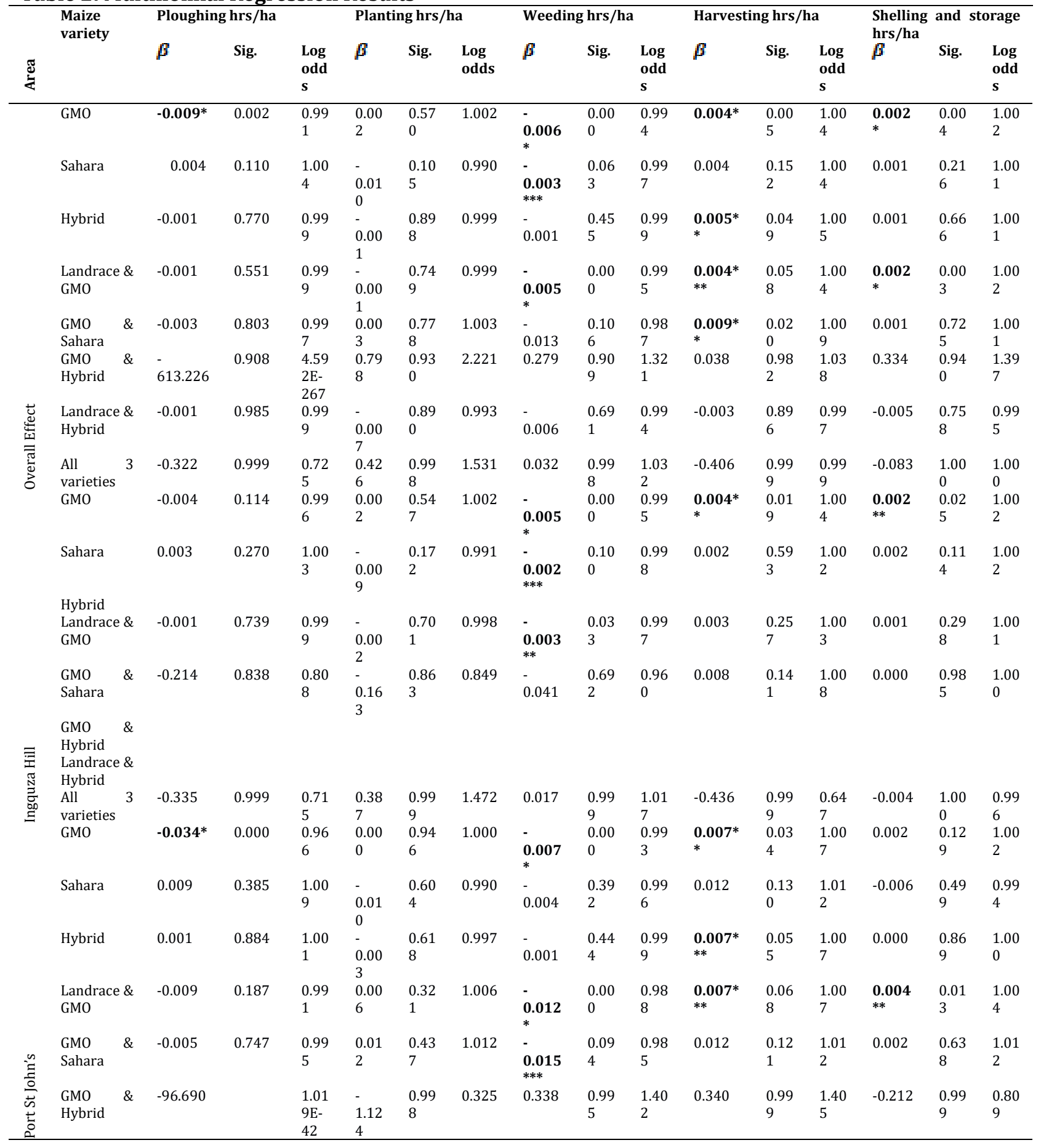


Journal of Economics and Behavioral Studies (ISSN: 2220-6140)

Vol. 10, No. 4, pp. 262-276, August 2018

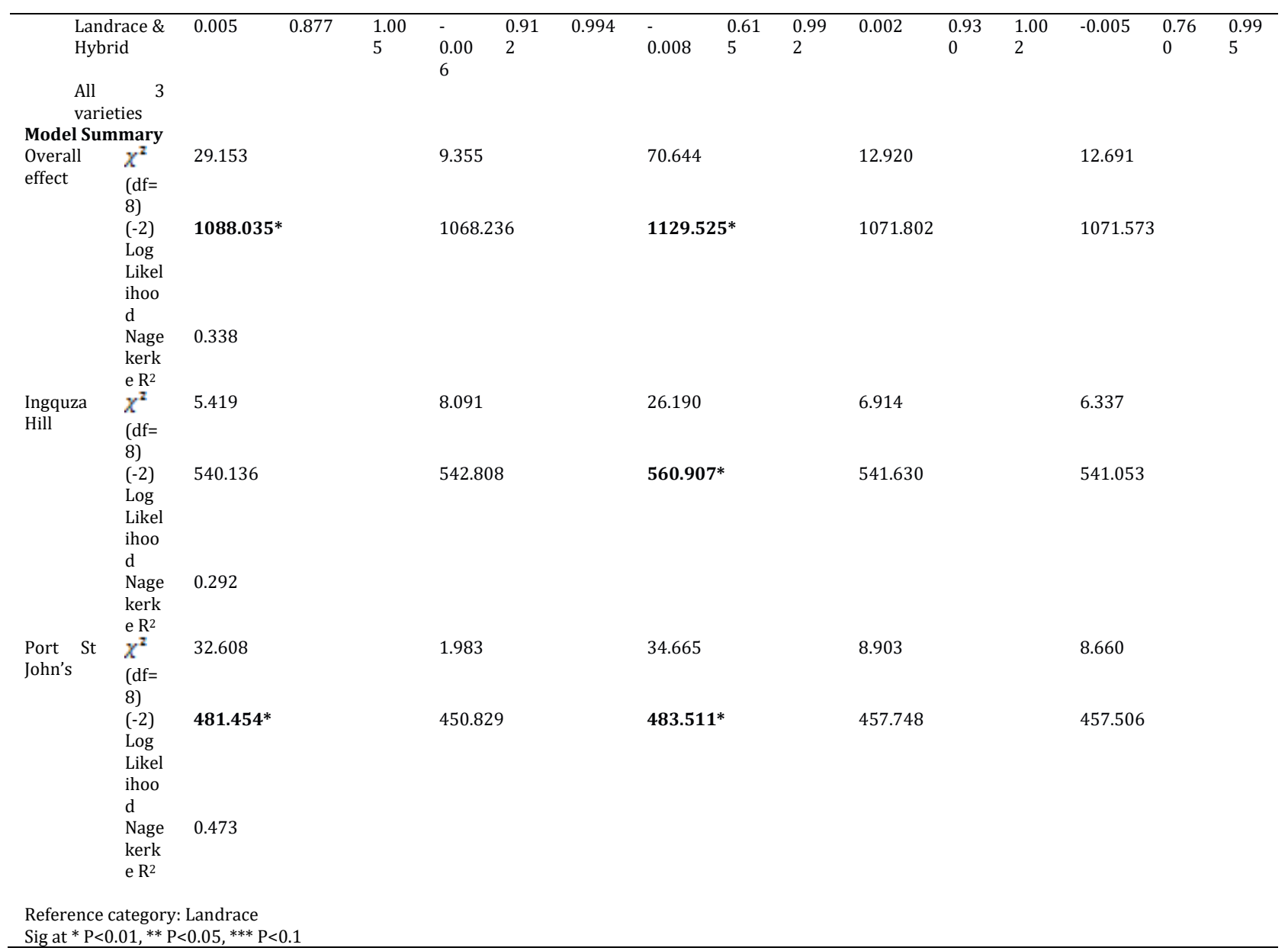

Table 3 below summarises the major maize crop husbandry practices that transiting from utilising landraces will influence. It is shown that weeding labour hours are most influenced, followed by harvesting, shelling and storage and then ploughing. The labour requirements in terms of planting are not affected.

Table 3: Changes in Labour Induced by Transiting from Landrace Variety

\begin{tabular}{|c|c|c|c|c|c|c|}
\hline & Maize variety & Ploughing & Planting & Weeding & Harvesting & $\begin{array}{l}\text { Shelling } \\
\text { and storage }\end{array}$ \\
\hline \multirow{8}{*}{ 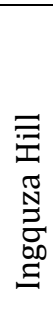 } & GMO & & & $\checkmark$ & $\checkmark$ & $\checkmark$ \\
\hline & Sahara & & & $\checkmark$ & & \\
\hline & Hybrid & & & & & \\
\hline & Landrace and GMO & & & $\checkmark$ & & \\
\hline & GMO and Hybrid & & & & & \\
\hline & Landrace and Hybrid & & & & & \\
\hline & All 3 varieties & & & & & \\
\hline & GMO & $\checkmark$ & & $\checkmark$ & $\checkmark$ & \\
\hline \multirow{6}{*}{ 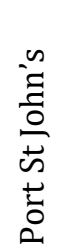 } & Sahara & & & & & \\
\hline & Hybrid & & & & $\checkmark$ & \\
\hline & Landrace and GMO & & & $\checkmark$ & $\checkmark$ & $\checkmark$ \\
\hline & GMO and Hybrid & & & $\checkmark$ & & \\
\hline & Landrace and Hybrid & & & & & \\
\hline & All 3 varieties & & & & & \\
\hline
\end{tabular}


Simulative results: Referring to table 3 transiting from landrace to GMO in Ingquza Hill and Port St John's as well as combining landrace and GMO in Port St John's had significant labour changes and thus were used in the simulation models. Figure 4 (a) shows that there is an $87.5 \%$ chance of the total labour hours to be between 450-1300 hours per hectare for maize farmers combining Landrace and GMO maize varieties in Port St John. The tonado Figure 4 (b) shows that shelling and storage is the activity with the highest labour hours followed by harvesting and weeding. The scatter plots with 5000 iterations (Figures 4(c), 4(d) and 4(e)) show that there is a higher correlation of the total labour hours per hectare with shelling and storage hours per hectare (accounting for 47.7\%) followed with harvesting (33.2\%) and weeding (31.9\%). In Figure 5 (a) there is a $90 \%$ possibility of total labour hours per hectare falling in the range 892 to 2692, with Figure 5 (b) showing that shelling and storage, weeding and ploughing were the most distinguishing from Ingquza Hill maize farmers using GMO maize varieties. The iteration shows a higher correlation between total labour per hectare with shelling and storage (accounting for $41.9 \%$ ), weeding (40.5\%) and harvesting (32.4\%) (Figures $5(c), 5(d)$ and $5(e))$.

Harvesting labour hours are significantly different when the maize producers transit from landrace to GMO $\left(P_{\text {value }}<0.05\right)$ in Ingquza Hill. The positive coefficient shows that the labour hours tend to increase in this instance. There is a $0.4 \%$ likely chance that harvesting hours will increase in this transition. This is also true for maize producers transiting from landrace to GMO ( $\left.P_{\text {value }}<0.05\right)$, Hybrid and combining GMO and landrace $\left(P_{\text {value }}<0.1\right)$ in Port St. John's. The likely chance of this occurring is $0.7 \%$ in each instance. Shelling and storage labour hours are significantly different when the maize producers change from landrace to GMO in Ingquza Hill and to combining with GMO $\left(P_{\text {value }}<0.05\right)$ in Port St John's. In both cases the positive coefficient suggests that labour hours tend to increase in such transitions. The likely chance of the shelling and storage labour hours increasing is $0.2 \%$ and $0.4 \%$ in Ingquza Hill and Port St. Johns respectively. The positive increase in labour hours in this instance can be explained by the improved yields that are obtained when the maize variety improves from landrace to the other varieties. Gouse (2014) explained this through an increase in yield per labour day, identifying an increase in maize output. The Nagekerke $\mathrm{R}^{2}$ values show that transitioning from landrace maize variety explains more labour dynamics in Port St. Johns than in Ingquza Hill, however, both values were low, requiring further variables to fully account for changes in maize varieties. The log likelihood values show that weeding hours are the major labour hours influenced by a change in the maize variety used, whilst in Port St John it is both ploughing and weeding hours.

\section{Figure 4: Monte Carlo Simulation Results}

(a)

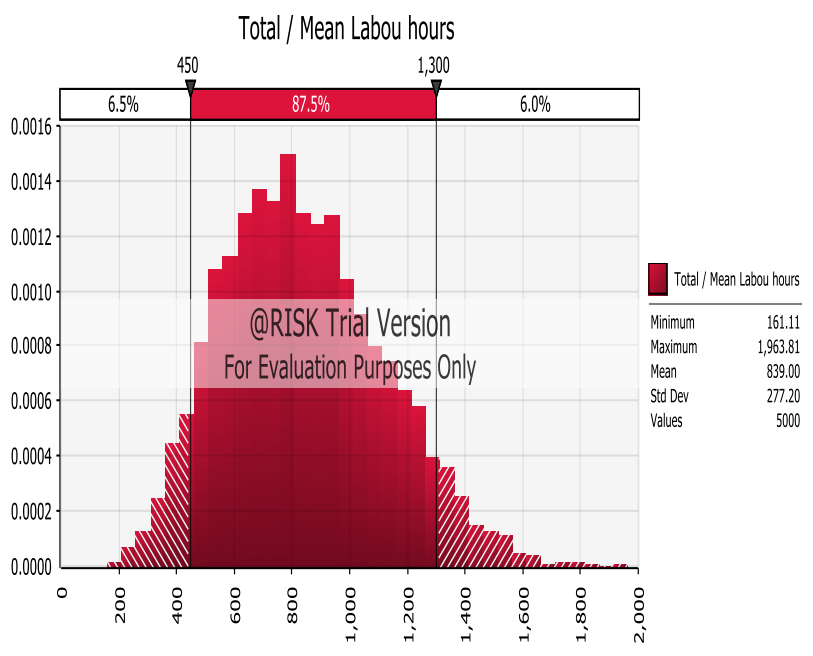

(b)

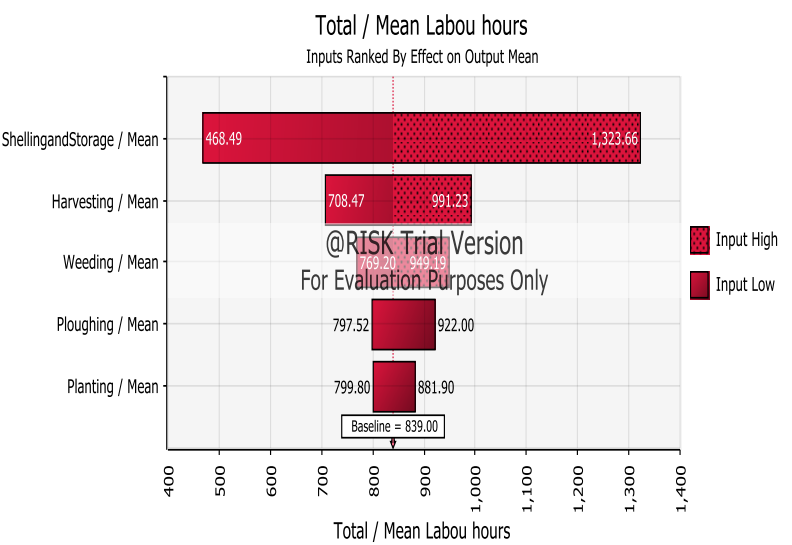


(c)

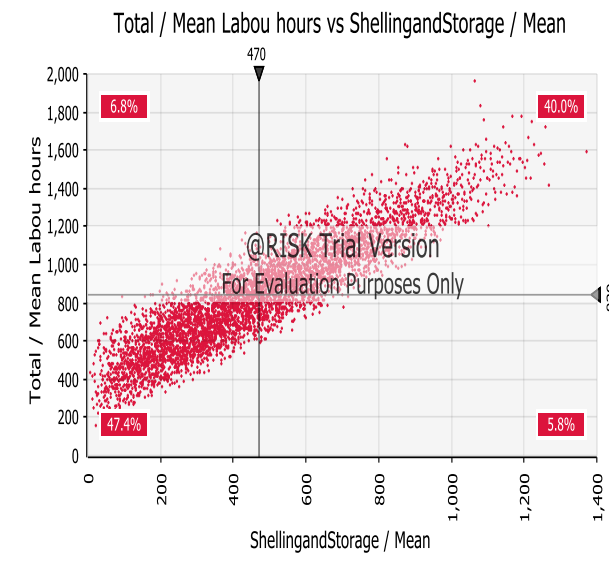

(e) (d)
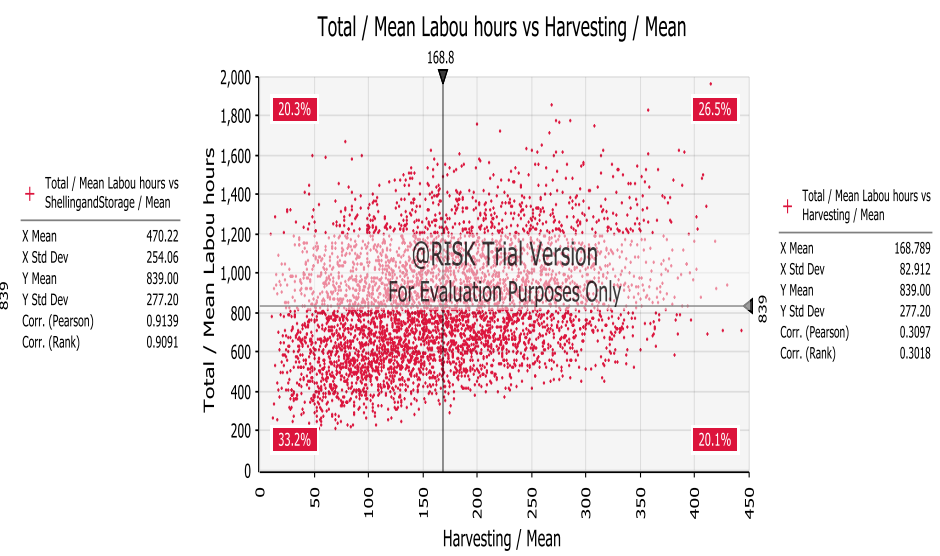

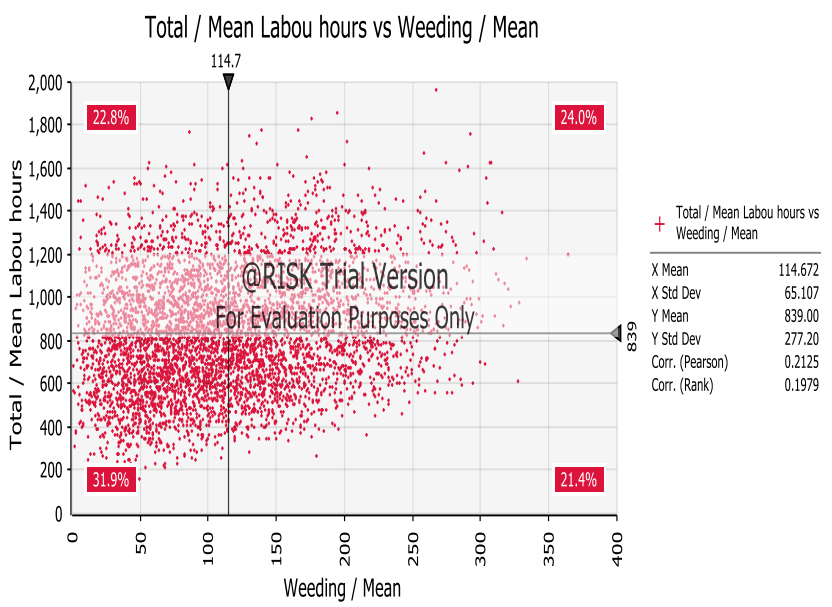

Iterations for Port St John's maize farmers combining Landrace and GMO varieties pertaining to (a) Mean Total Labour hours/ha, (b) Tonado of most significant Labour contributions (c) scatter plot of Mean Total Labour/ha vs Shelling and Storage Labour/ha (d) scatter plot of Mean Total Labour/ha vs Harvesting Labour/ha and (e) Mean Total Labour/ha vs Weeding Labour/ha

\section{Figure 5: Monte Carlo Simulation Results}

(a)

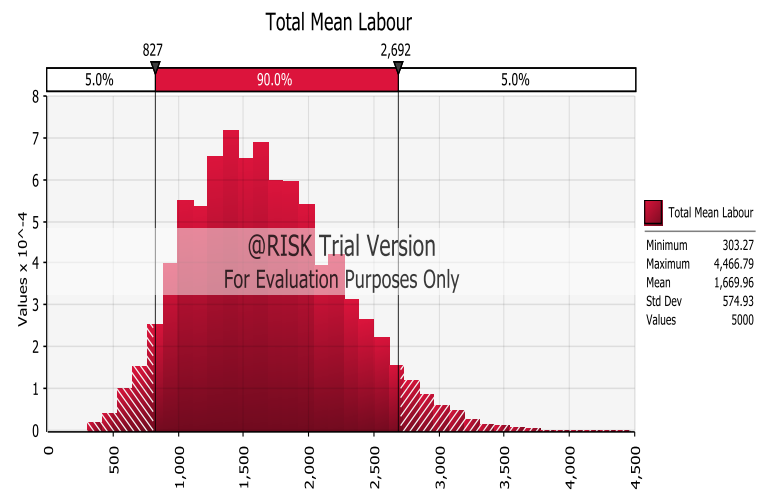

(b)

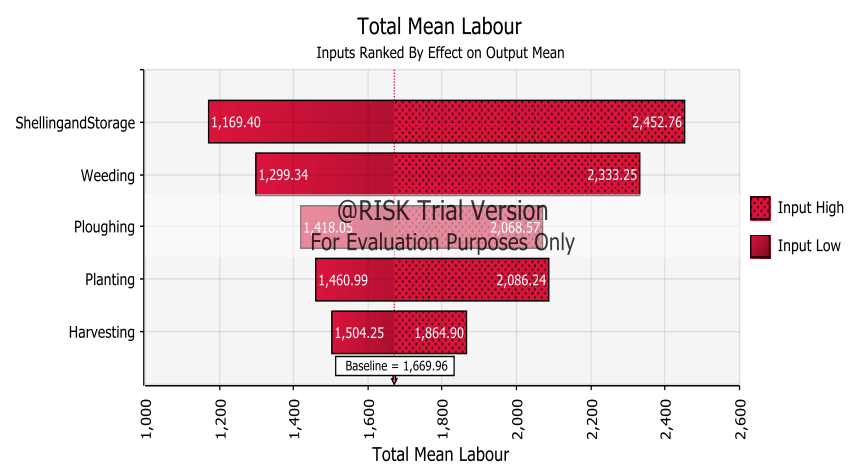


(c)

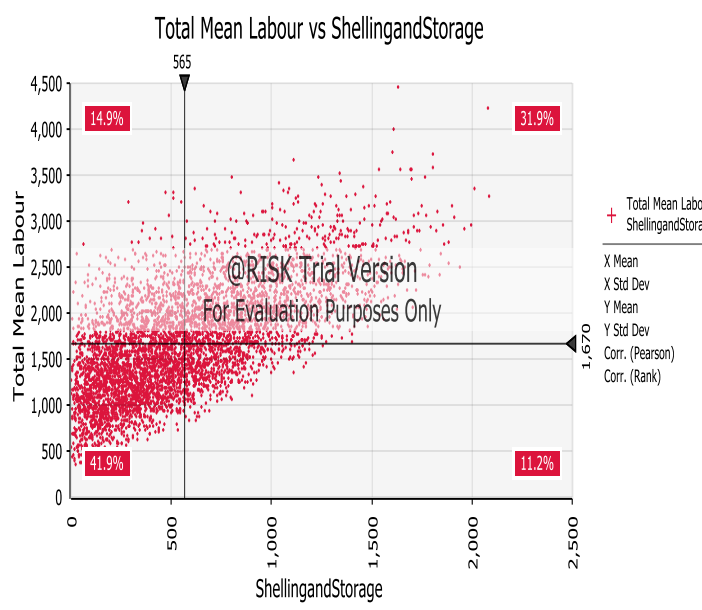

(e)

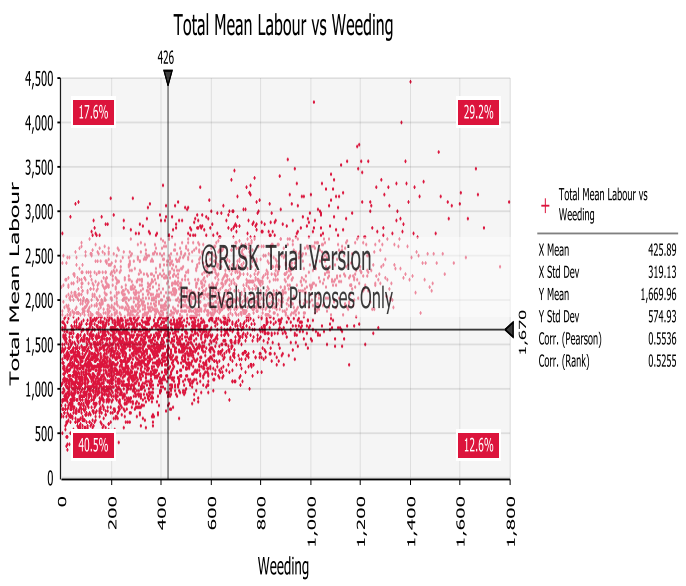

(d)

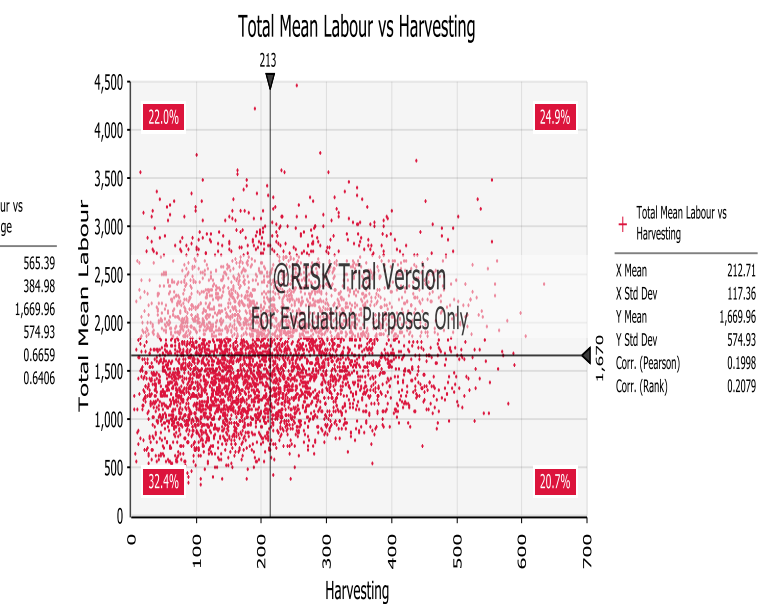

Iterations for Ingquza Hill's maize farmers with GMO varieties pertaining to (a) Mean Total Labour hours/ha, (b) Tonado of most significant Labour contributions (c) scatter plot of Mean Total Labour/ha vs Shelling and Storage Labour/ha (d) scatter plot of Mean Total Labour/ha vs Harvesting Labour/ha and (e) Mean Total Labour/ha vs Weeding Labour/ha

Figure 6: Monte Carlo Simulation Results

(a)

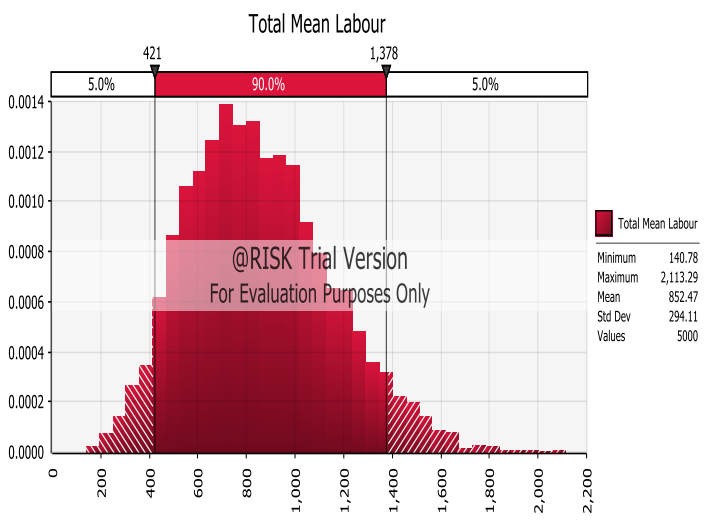

(b)

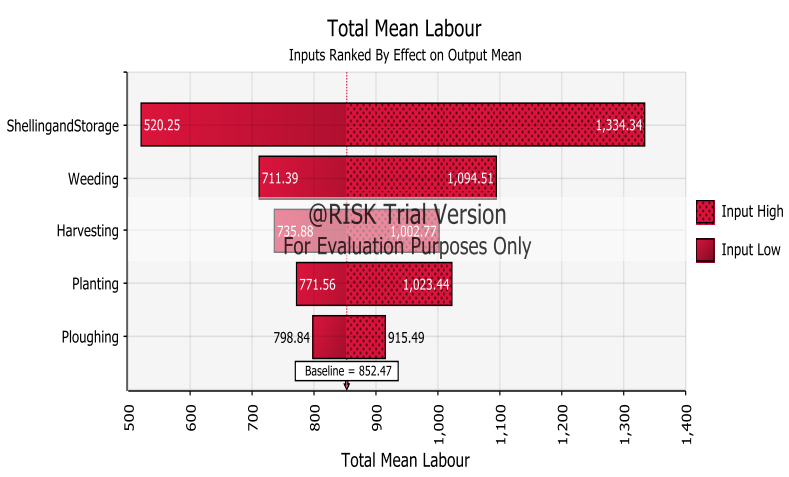

273 
(c)

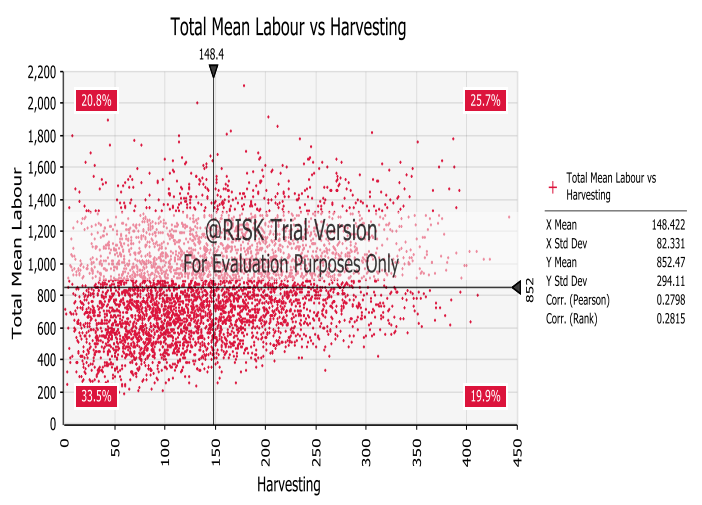

(e)

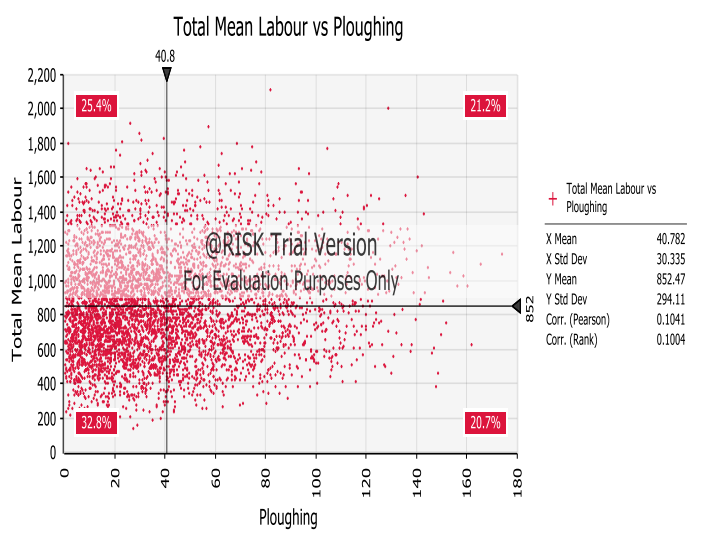

(d)

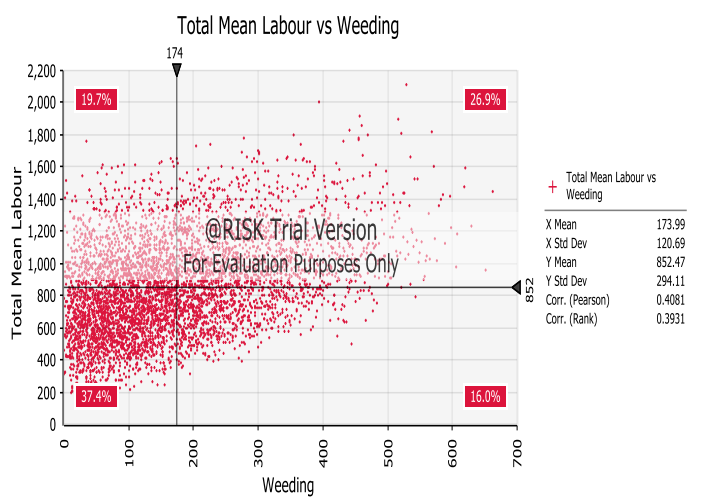

Iteration Port St John's maize farmers with GMO varieties pertaining to (a) Mean Total Labour hours/ha, (b) Tonado of most significant Labour contributions (c) scatter plot of Mean Total Labour/ha vs Shelling and Storage Labour/ha (d) scatter plot of Mean Total Labour/ha vs Harvesting Labour/ha and (e) Mean Total Labour/ha vs Weeding Labour/ha

Figure 6 (a) shows a 90\% chance of mean total labour hours per hectare to fall between 421 and 1378 hours for GMO only variety users in Port St John's, being accounted for shelling and storage, weeding and harvesting hours per hectare (Figure 6 (b)). The iterations however reveal a somewhat scattered plot, with weeding having the highest account for $37.4 \%$ of the mean total labour followed by harvesting $(33.5 \%)$ and then ploughing (32.8\%). Alhassan et al. (2016), Gouse (2014) and Gouse et al. (2006) findings of weeding laying bedrock in determining maize yields, through improved maize variety adoption. Regier and Dalton, (2013) explain this through the weeding labour being replaced by herbicide use when the maize variety improves.

\section{Conclusion and Recommendations}

In conclusion, utilising GMO varieties appear to have more impact in terms of labour use in the two study sites. It has a bearing on the weeding, harvesting, shelling and storage labour in Ingquza Hill. In Port St John's, GMO utilization tends to have a bearing on ploughing, weeding as well as harvesting hours. Overall, weeding labour hours were seen to be mostly affected by the use of improved maize varieties. Utilising improved maize varieties tends to reduce the weeding labour requirements. However, as the output increases from the use of the improved varieties, harvesting, shelling and storage labour hours tend to increase, also having a bearing on labour requirements. The simulations do however show an increased impact of maize variety utilisation on harvesting as well as on shelling and storage labour hours. This is accounted for by the increased yields envisaged in improved maize varieties. The study recommends the promotion and uptake of improved maize varieties especially GMO mainly based on two fronts: (1) there is reduced labour hours in the 
tedious husbandry practices of ploughing and weeding, freeing labour for other household chores as well as (2) the possibilities of creating employment opportunities especially when high yields are realised requiring more labour in terms of harvesting, shelling and storage. Labour should thus be recalibrated to focus on harvesting, shelling and storage if the increased output envisaged from improved maize varieties is not to overshadow the shift in labour use.

\section{References}

Alhassan, A., Salifu H. \& Adebanji A. O. (2016). Discriminant Analysis of Farmers Adoption of Improved Maize Varieties in Wa Municipality, Upper West Region of Ghana, Springer Plus, 5, 1514.

Bamire, S. A., Abdoulaye T., Amaza P., Tegbaru A., Alene A. D. \& Kamara A. Y. (2010). Impact of Promoting Sustainable Agriculture in Borno (PROSAB) Program on Adoption of Improved Crop Varieties in Borno State of Nigeria, Journal of Food, Agriculture and Environment, 8(3\&4), 391-398.

Department of Local Government. (2012). The Local Government Handbook. A complete guide to municipalities in South Africa: OR Tambo District Municipality (DC15). Available on the World Wide Web: $\quad$ http://www.localgovernment.co.za/districts/view/6/OR-Tambo-District-Municipality. [Accessed on 30 November 2015].

ECSECC. (2014). Eastern Cape Socio-Economic Consultative Council; O.R. Tambo, Eastern Cape: 2014 SocioEconomic profile. Available on the World Wide Web:http://www.ecsecc.org/files/library/documents/ECSECC_OR_Tambo_SP_2014.pdf [Accessed 01 October 2015].

Gouse, M. (2014). Seed Technology and Production System Comparisons-South African Subsistence/Smallholder Farmers, Creating a Community of Practice in KwaZulu Natal-a Templeton Foundation Supported Project Report

Gouse, M., Piesse, J. \& Thirtle, C. (2006). Output and labour effects of GM maize and minimum tillage in a communal area of KwaZulu Natal. Journal of Development Perspectives, 2(2).

Gouse, M., Piesse, J., Thirtle, C. \& Poulton, C. (2009). Assessing the performance of GM maize amongst smallholders in KwaZulu-Natal, South Africa. Ag Bio Forum, 12(1), 78-89.

Gouse, M., Sengupta, D., Zambrano, P. \& Zepeda, J. F. (2016). Genetically Modified Maize: Less Drudgery for Her, More Maize for Him? Evidence from Smallholder Maize Farmers in South Africa, World Development, 83, 27-38.

Global Harvest Initiative. (2017). \#Science Matters: Biotech Maize Reduces Labor for Women Farmers, http://www.globalharvestinitiative.org/index.php/2017/04/sciencematters-biotech-maizereduces-labor-for-women-farmers/

IDP. (2016). OR TAMBO District Municipality Integrated Development Plan Review 2016/17, http://ortambodm.gov.za/download/IDP-2016-17-27-May-2016.pdf [accessed 30 May, 2017]

IDP. (2009). Ingquza Hill Local Municipality Integrated Development Plan Review 2009/2010

James C. (2014). Global Status of Commercialized Biotech/Gm Crops: 2014, International Service for The Acquisition of Agri-Biotech Application (ISAAA), Brief 49, Ithaca, NY

Karim M. R., Moniruzzaman. \& Alam, Q. M. (2010). Economics of Hybrid Mazie Production in Some Selected Areas of Bangladesh, Bangladesh, J. Agri Res, 35(1), 83-93.

KPA, 3. (n. d.). Support Programme to "Decentralisation and Local Development Policies in South Africa: A Network of Tuskan and South African Local Government": Eastern Cape Report

Kristensen, A. R. \& Pedersen, C. V. (2003). Representation of Uncertainty in a Monte Carlo Simulation Model of a Scavenging Chicken Production System. In EFITA Conference (451-459). Debrecen, Hungary, 5-9 July.

Leonardo, W. J., van de Ven, G. W. J., Udo H., Kanellopoulos, A., Sitoe, A. \& Giller, K. E. (2015). Labour not Land Constraints Agricultural Production and Food Self-Sufficiency in Maize-Based Smallholder Farming Systems in Mozambique, Food Security, 7, 857-874.

Mandikiana, B. W. (2011). Economics of Bt maize yield guard production case of small holder farmers in the Eastern Cape Province (Masters dissertation, University of Fort Hare).

Mary, S., Phimister, E. \& Roberts, D. (2013). Testing the sensitivity of CGE models: A Monte Carlo filtering approach to rural development policies in Aberdeenshire. Luxembourg 
Mbofung, C. M. F. (2010). The Role of GMOs in Africa: Food and Nutrition Security, GMOs for African Agriculture: Challenges and Opportunities Workshop Report, Academy of Science of South Africa (ASSAf), Pretoria, ISBN: 978-0-9814159-7-0

McCann, M. (n. d.). Annexure 5: District Profile Eastern Cape 0. R. Tambo District Municipality (DC 15): Programme of Support to Local Economic Development in the Eastern Cape: Eastern Cape Competitive Advantage Assessment and Training Support Project, European Consultants Organization, AMS/451-LOT $\quad \mathrm{N}^{0} \quad$ 9, Mission N02005/109496http://www.ecsecc.org/documentrepository/informationcentre/030407135344.pd $\mathrm{f}$

Ouma, J. O. \& De Groote, H. (2011). Determinants of Improved Maize Seed and Fertilizer Adoption in Kenya, Journal of Development and Agricultural Economics, 3(11), 529-536.

ORTDM. (2007). O. R. TAMBO District Municipality, District Growth and Development Strategy, Position Paper on Agriculture Sector, February

PSJM. (n. d.). Port St John Municipality, https://www.psjmunicipality.gov.za/index.php/local-economicdevelopment-managers-responsibilities/ [accessed 30 May, 2017]

Quantec easy data. (2017a). Maize: Area Planted [database], Available on the World Wide Web: www.easydata.co.za/data/timeseries/AGR-T007S002/ [accessed 30 May, 2017]

Quantec easy data. (2017b). Maize: Area Planted [database], Available on the World Wide Web: www.easydata.co.za/data/timeseries/AGR-T007S001/\# [accessed 30 May, 2017]

Regier, G. K. \& Dalton, T. J. (2013). Labour-Savings of Roundup Ready Maize: Impact on Cost and Input Substitution for South African Smallholders, $4^{\text {th }}$ International Conference of the African Association of Agricultural Economists, 22-25 September

South Africa Explorer. (2014). Flagstaff and Port St Johns climate.

SALN. (n. d.). Port St John Development Agency: About this Community of Practice, http://led.co.za/leda/port-st-johns-development-agency

Sibiya J., Tongoona P., Derera J. \& Makanda I. (2013). Farmers' Desired Traits and Selection Criteria for Maize Varieties and Their Implications for Maize Breeding: A Case Study from KwaZulu-Natal Province, South Africa, Journal of Agriculture and Rural Development in the Tropics and Subtropics,114(1), 3949.

Schwab, J. A. (2002). Multinomial logistic regression: Basic relationships and complete problems. http://www.utexas.edu/courses/schwab/sw388r7/solvingproblems.

The Economic Times. (2018). Definition of "Monte Carlo Simulation", https://economictimes.indiatimes.com/definition/monte-carlo-simulation [accessed 12 March, 2018]

World Bank. (2008). World Development Report 2008: Agriculture for Development, Washington DC: World Bank.

\section{Acknowledgement}

The authors acknowledge BioSafety South Africa ${ }^{\circledR}$ for financing this study. 